\section{Incidence of self-reported hearing loss and associated risk factors among the elderly in São Paulo, Brazil: the SABE survey}

\author{
Incidência de deficiência auditiva referida em \\ idosos no Município de São Paulo, Brasil, \\ e fatores associados: Estudo SABE \\ La incidencia de pérdida de la audición auto- \\ reportada entre los ancianos en São Paulo, \\ Brasil, y factores asociados: Estudio SABE
}

Mariana Sodario Cruz 1

Maria Cristina Pereira Lima 2

Jair Lício Ferreira Santos 3

Maria Lúcia Lebrão 4

Yeda Aparecida de Oliveira Duarte 5

Ana Teresa de Abreu Ramos-Cerqueira 2

\footnotetext{
${ }^{1}$ Faculdade de Ceilândia, Universidade de Brasília, Brasília, Brasil.

2 Faculdade de Medicina de Botucatu, Universidade Estadual Paulista, Botucatu, Brasil.

${ }^{3}$ Faculdade de Medicina de Ribeirão Preto, Universidade de São Paulo, Ribeirão Preto, Brasil.

4 Faculdade de Saúde

Pública, Universidade de São Paulo, São Paulo, Brasil.

5 Escola de Enfermagem. Universidade de São Paulo, São Paulo, Brasil.

Correspondence M. S. Cruz

Faculdade de Ceilândia, Universidade de Brasília. QNN 14 Área Especial, Ceilândia Sul, Brasília, DF 71926-000, Brasil. msodario@yahoo.com.br
}

\begin{abstract}
This study aimed to estimate the incidence of self-reported hearing loss among the elderly in the city of São Paulo, Brazil, and identify associated risk factors. A longitudinal study based on a representative sample of individuals aged 60 years and over interviewed in 2000 was conducted in 2006. The sample was obtained in two stages using the cluster sampling method, adopting the criterion distribution proportional to size, and replacement with probability proportional to population for subjects aged 75 years and over. Statistical analysis was performed using the likelihood ratio test to compare survival curves based on the Cox regression model. A total of 765 individuals were interviewed. The hearing loss incidence rate was 28.9/1,000 persons/year and proportional incidence was $17.4 \%$. Associated risk factors were being aged 80 years and over, being male, having an occupation related to agricultural, industrial or maintenance sectors and having osteoporosis. Steps must be taken to reduce incidence by ameliorating the risks identified, particularly those related to occupational noise and specific diseases, notably osteoporosis.
\end{abstract}

Hearing Loss; Health of the Elderly; Aged

\section{Resumo}

O objetivo foi estimar a incidência de deficiência auditiva referida por idosos em São Paulo, Brasil, e fatores de risco associados. Realizou-se estudo longitudinal em 2006, baseado na população com 60 anos ou mais entrevistada em 2000. A amostra foi obtida pelo método de amostragem por conglomerados, em dois estágios, sob critério de partilha proporcional ao tamanho, com reposição e probabilidade proporcional à população, para sujeitos com 75 anos ou mais. A análise estatística foi realizada pelo teste de razão de verossimilhança para a igualdade das curvas de sobrevivência e regressão de Cox. Foram entrevistados 765 idosos, com taxa de incidência de deficiência auditiva referida de 28,9/1.000 pessoas-ano e proporção da mesma de $17,4 \%$. Os fatores de risco associados foram idade igual ou maior a 80 anos, sexo masculino, ocupações nos setores agropecuário, industrial ou de manutenção e osteoporose. Medidas de atenuação de risco devem ser elaboradas para a diminuição da incidência da deficiência auditiva entre os idosos, principalmente as relacionadas à prevenção do ruído ocupacional e de doenças, em especial a osteoporose.

Perda Auditiva; Saúde do Idoso; Idoso 


\section{Introduction}

Presbyacusia is hearing loss associated with aging and one of the most prevalent chronic conditions among the elderly 1 . It is thought to be caused by a combination of organic, environmental and life-style-related factors such as genetic predisposition 2, exposure to noise, use of ototoxic drugs and the effects of illnesses suffered over the course of a lifetime ${ }^{3}$.One consequence of hearing loss is that it makes communication difficult, increasing the possibilities of social isolation, that in turn has a considerable effect on the daily activities and functional capacity of the elderly 4 . Presbyacusia is considered a significant public health problem due to the high prevalence of this condition among the elderly population.

In the United States, around $30 \%$ of the population aged 70 years and over are self-reported as having a hearing impairment and this figure reaches $50 \%$ in the over- 80 age group 5 . In 2003 and 2004, $16.1 \%$ of young adult and elderly Americans, equivalent to approximately 29 million people, were afflicted by hearing deficiencies. Moreover, prevalence was five times greater in males than in females and five times greater in Caucasians than in African-Americans. Onset of hearing loss also occurred earlier in smokers, in people exposed to occupational noise and in people with associated diseases, such as cardiovascular conditions 6 , to the extent that it is the third most prevalent chronic condition experienced by the American population 7 .

Incidence of hearing loss among the American population was reported by Cruickshanks et al. 8 based on audiometric data collected over a period of five years. Mitchell et al. ${ }^{9}$, using a similar time period in a study in Australia of 3,654 individuals aged 50 years and over, found that hearing loss incidence was $17.9 \%$ and associated risk factors were advancing age and a less-privileged professional occupation.

In Brazil, hearing loss prevalence rates among the elderly vary between $13.8 \%$ and $33.3 \%$ in São Paulo $10,26.8 \%$ in the Northeast Region $11,36 \%$ in Canoas in the State of Rio Grande do Sul 12 and between $42.9 \%$ and $64.3 \%$ in Rio de Janeiro 13 . Despite the above figures, population studies of hearing loss among the elderly in Brazil are rare, especially those using longitudinal data to measure risks associated with this morbidity. In the bibliographic databases consulted for this article, no publications on hearing loss incidence among the elderly were found that contained nationwide data.

The Pan American Health Organization coordinated the Health, Well-being and Aging Survey (Saúde, Bem-Estar e Envelhecimento - SABE, ac- ronym in Portuguese) 14 to fill this information gap, obtain other epidemiological information related to the elderly and obtain a profile of the living conditions and state of health of the elderly in Latin America and the Caribbean.

This paper is part of the SABE survey and aims to estimate self-reported hearing loss incidence among the elderly in the city of São Paulo, and identify the risk factors associated with this condition, to provide input for the elaboration of public policies directed at hearing loss prevention in this group.

\section{Methods}

The SABE survey was initiated in 2000 and its first phase consisted of a broad ranging simultaneous, multicentric, strictly comparative study, covering Argentina, Barbados, Brazil, Chile, Cuba, Mexico and Uruguay.

Data was collected on the following aspects of elderly life: personal information, cognitive function, state of health, functional condition, use of medications, use of and access to health services, family and social support network, occupational background and source of income, housing conditions, anthropometrics, and flexibility and mobility.

The sample was made up of two segments. The first, consisting of a probabilistic sample of 1,568 interviewees, was drawn from permanent records of 72 census tracts from the 1995 Brazilian National Household Sample Survey (Pesquisa Nacional por Amostra de Domicilios - PNAD, acronym in Portuguese) available at the Department of Epidemiology of the Faculty of Public Health of the University of São Paulo (FSP-USP). The PNAD records are composed of 263 census tracts drawn through cluster sampling using the criterion probability proportional to the number of households. The second segment consisted of 575 individuals living in the districts in which the preceding interviews had been conducted, and constituted additions made to compensate for mortality among elderly people aged over 75 years and to complete the desired number of interviews within this age group. This was done by locating households in close proximity to the selected census tracts or within the boundaries of the districts where the selected census tracts were located. The minimum number of households selected in the second stage approximated 90 .

Questionnaire weighting was calculated according to the corresponding census sector (weight=1/f). For questionnaires conducted with individuals from households which were part of 
the original sample, weighting was calculated based on the relation between the population of São Paulo aged 75 years and over in 1998 and the total number of individuals from this age group registered in the final sample of the study.

Phase 2 of the SABE survey began in 2006, this time as a longitudinal survey. The aim of the second phase was to study changes over time in living conditions and health status of elderly people in the city of São Paulo and their associated determinants. To that end, the elderly individuals from the first phase of the study were revisited and reassessed. The basic aspects of the questionnaire were maintained, with slight modifications to address the study's requirements.

The study sample consisted of the individuals from the SABE survey 2000 sample aged 60 years and over who were reassessed in 2006. The baseline or initial population was determined as all individuals who had not self-reported hearing loss in $2000(n=1,396)$. The methodology included the study of concurrent cohorts, whereby the final event was considered to be self-reporting of hearing loss after the monitoring period had begun. Other exclusion factors, in addition to presence or absence of hearing loss at the beginning of the study segment, were taken into account, such as mortality over the period of the study $(\mathrm{n}=$ $366)$, failure to locate the subject $(n=98)$, change of residence to another city $(n=31)$, admittance to an institution $(n=5)$ or refusal to continue to participate in the second phase of the survey $(n=$ 131), as illustrated in Figure 1.

The final sample consisted of 765 elderly individuals interviewed first in 2000 and again in 2006. The criterion used to register self-reported hearing loss was the individual's response to the question "Generally speaking, how would you rate your hearing (with or without a hearing aid)?". The answers fair, poor, very poor, or if the subject remarked that he or she used a hearing aid, were all considered self-reported hearing loss. The original questionnaire was maintained from one data gathering period to the other, except for the addition of specific questions on hearing aid use, including "Why don't you use a hearing aid?". The information resulting from this question showed that certain elderly individuals had been prescribed hearing aids but had not been fitted with them. This aspect was therefore also included as an indication of self-reported hearing loss in 2006.

The following possible risk factors were examined: age, sex, skin color or ethnicity, marital status, family arrangement, literacy, education level (years of schooling), income, perception of income, occupational category, occupation position, self-perception of health, self-report- ed visual deficiency, tobacco use, diabetes, hypertension, osteoarticular diseases, neoplasia, cardiovascular disease, osteoporosis, chronic obstructive pulmonary disease, dizziness, symptoms of depression, probable dementia, use of estrogens (hormone replacement) and the presence of morbidities associated with the individual's occupation.

The Geriatric Depression Scale, developed by Sheik \& Yesavage 15 to detect symptoms of light or serious depression in the elderly, was used to investigate symptoms of depression. Cognitive functions were evaluated using a modified version of the MEEM (Mini-Mental Health Exam), originally developed by Folstein et al., validated in Chile 16,17. The 12/13 cutoff point was adopted in accordance with the validation study recommendation. Sensitivity and specificity were $93.8 \%$ and $93.9 \%$, respectively 16 , and cognitive impairment was defined based on a points scale with a maximum score of 12 .

The MEEM results were used as a filter for the use of the Pfeffer Functional Activities Questionnaire (PFAQ) developed by Pfeffer et al. 18 and designed to evaluate an individual's functional autonomy regarding daily activities. A cutoff point of six or over, recommended by the authors, was adopted to indicate that an individual requires assistance to undertake instrumental activities of daily living. For analysis purposes, a subject that scored points in both the MEEM and the PFAQ was classified as a probable case of dementia.

With respect to the analysis of occupations, the individual's last or current occupation was investigated using the question: "What is the name of the job or occupation you were engaged in last week or the last time you worked?".

Occupations were coded in accordance with the definitions adopted by the Brazilian Classification of Occupation (http://www.mtecbo. gov.br/cbosite/pages/home.jsf). Professions were grouped according to the following criteria: whether they offered a similar degree of risk for hearing, such as the presence of background noise in the working environment; whether they had similar educational requirements; or whether they involved tasks of a similar nature. This system of categorization resulted in the following new groups: Group 1 - members of the armed forces, police force, fire brigade, civil service administrators, managers of civil society organizations of relevant public interest and of companies, managers, and professionals in the areas of science and the arts; Group 2 - individuals with higher-level secondary technical qualifications, administrative services employees and service workers, salespersons in shops and markets; Group 3 - agricultural and livestock production 


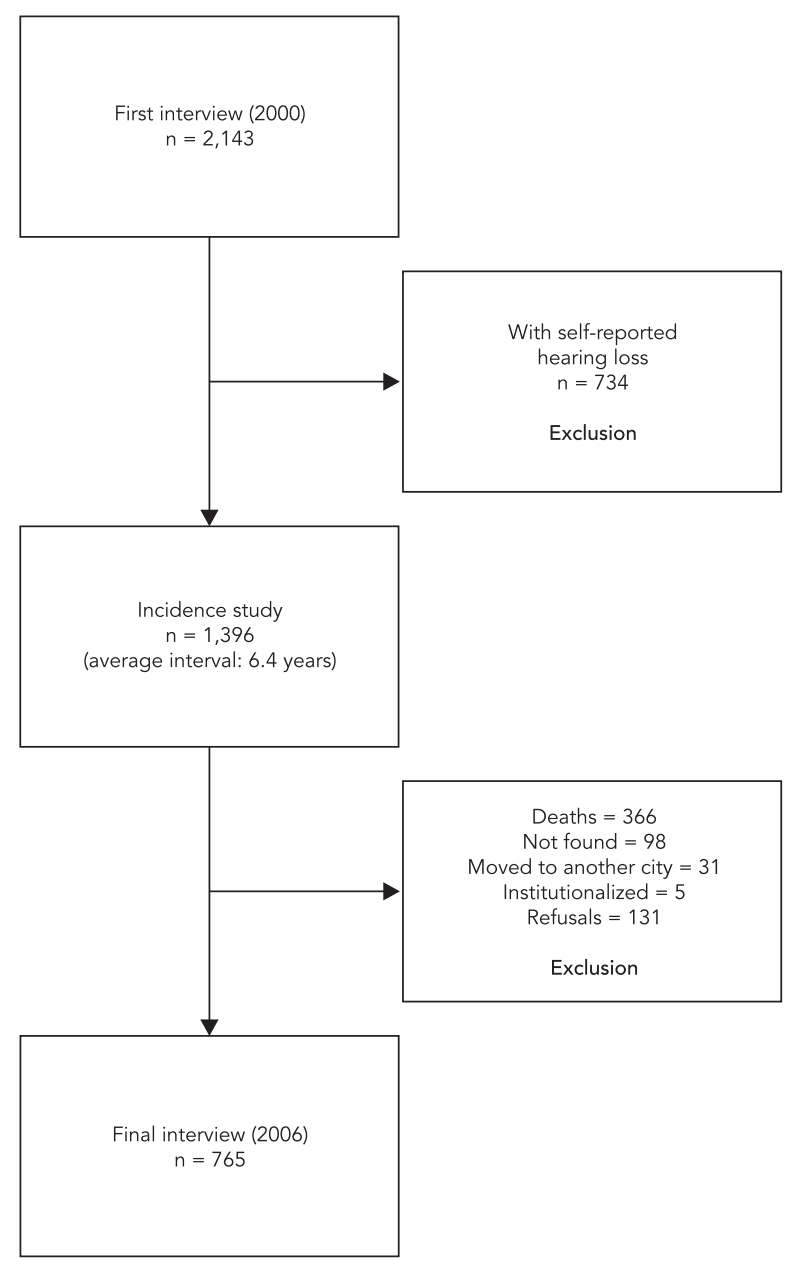

workers, forestry workers, hunters and fishermen, production workers in industrial manufacturing and services and maintenance and repair workers.

Although individuals belonging to the armed forces, police force and the fire brigade experienced the greatest degree of exposure to occupational noise (due to the use of firearms), we decided to maintain these individuals in the first group due to their higher level of education and also because of the small overall number of individuals in the research sample.

Data analysis was carried out using the Stata 10.0 program (Stata Corp., College Station, U.S.A.) to handle the complex sampling method, involving a non-proportional stratified random sample and weighting. The weight variable created to assign different weights to the data was defined by calculating the reciprocal of the sample fraction and adjusted to ensure that the sample did not present any distortions regarding age or sex.

To analyze factors associated with hearing loss, survival curves based on the Cox regression model were plotted for each factor and compared using the verisimilitude ratio test. For analysis purposes, and to facilitate the calculation of estimated incidence rates, it was assumed that individuals acquired the condition in the middle of the period studied. Cumulative (proportional) incidence was calculated based on the total population at the beginning of the study, with values expressed as percentages. 
A multivariate analysis of the independent variables that obtained $\mathrm{p}<0.20$ in the single variable analysis was carried out using the Cox model. A backward stepwise procedure was then used to construct the multiple model which analyzed the variables that obtained a $p$-value $\leq 0.05$. In the final analysis, relative risk or risk ratio was estimated for each retained variable together with the $95 \%$ confidence interval.

This study is an integral part of the SABE survey, which was approved by the Research Ethics Committee of the FSP-USP (research protocol 1345, official document reference: COEP/83/06), which authorized the present study as a subproject.

\section{Results}

The average time elapsed between the first and second interviews was 6.4 years (SE 0.03) and the average estimated time since the onset of selfreported hearing loss was 3.2 years (SE 0.15). Of the 765 elderly individuals interviewed, $36.4 \%$ $(\mathrm{n}=255)$ were males and $63.6 \%(\mathrm{n}=510)$ females. Based on the data collected at the beginning of the survey, mean age was 68.6 years (SE 0.6) and most of the elderly individuals (80.0\%) were literate and had a family income that was higher than the official minimum wage $(70.3 \%)$.

Proportional incidence of self-reported hearing loss over the period was $17.4 \%$ (95\%CI: 14.8 20.2), with $n=142$. The incidence of self-reported hearing loss was 28.9 new cases per 1,000 personyears. Incidence rates specified by individual risk factors are set out in Tables 1 and 2 .

The following variables were included in the multivariate analysis: age group, sex, marital status, family structure, occupational group, self-perception of health, tobacco use, osteoporosis and the use of some kind of medication. The findings of the multiple-analysis and the variables retained in the final model (with $\mathrm{p}$ values $\leq 0.05$ ) are displayed in Table 3 .

Individuals in the 80 years and over age group were $70 \%$ more likely to develop hearing loss than those in the 60 to 69 years age group. Men also showed a $80 \%$ greater risk of developing hearing loss than women and those whose last or current occupation was in industry, agricultural and livestock production or maintenance were $70 \%$ more at risk than those in other occupations. Individuals with osteoporosis also showed a $70 \%$ greater risk of developing hearing loss than those without the disease.

\section{Discussion}

Very few studies have used longitudinal data to investigate hearing in young people or adults. The most notable work was conducted by Cruickshanks et al. 8, Lee et al. 19, Mitchell et al. 9 and Cruickshanks et al. 20. However, findings relate either to proportional incidence or to alterations in hearing thresholds over time and none of these studies report incidence rates (number of new cases per population per year) in the studied sample groups. It is therefore impossible to make direct comparisons between the incidence rates identified by the present study (28.9/1,000 person-years) and those reported in the literature.

Despite this difficulty, the high incidence rates detected by this study stand out, especially in the more advanced age groups, emphasizing the need for research into auditory health in the elderly and investigate measures for ameliorating the risk of hearing loss in this age bracket to reduce such high incidence rates.

Proportional incidence observed by this study (17.4\%; 95\%CI: 14.8-20.2) is very similar to that reported by Mitchell et al. 9 (17.9\%; 95\%CI: 15.4-20.5) and Cruickshanks et al. 8 (21\%; 95\%CI: 19.4-23.4) in studies that investigated similar time intervals to the present study (five years). However, it is important to note that these studies used different methodologies and studied different age groups. Mitchell et al. ${ }^{9}$ and Cruickshanks et al. 8 studied individuals aged 50 years and over and 48 years and over, respectively, using audiometric measures, as opposed to the present study that investigated individuals aged 60 years and over through the use of questionnaires. Therefore, despite the apparent similarities between the studies, it is reasonable to assume that the values for self-reported hearing loss are underestimated, and higher proportional incidence rates should be expected for older individuals, particularly those over the age of 60 . On the other hand, if proportional incidence was considered as being accumulated prevalence and elderly individuals acquired hearing loss before reaching the specific age of the study group investigated by the present study, it is possible that similar incidence values would be found.

The following variables showed the greatest degree of association with the highest incidence of hearing loss and can therefore be considered risk factors for hearing loss: being aged 80 years and over, being male, working or having worked in agriculture or livestock production, industry or maintenance, and having osteoporosis.

The risk of experiencing hearing loss was $50 \%$ greater in individuals aged 70 years and over and $70 \%$ greater in individuals aged 80 years and over, 
Table 1

Self-reported hearing loss incidence (per 1,000 person-years) among elderly individuals according to sociodemographic factors. The SABE study, São Paulo, Brazil, 2000 and 2006.

\begin{tabular}{|c|c|c|c|}
\hline Variable & $n$ & Incidence $(95 \% \mathrm{Cl})$ & $p$-value \\
\hline \multicolumn{4}{|l|}{ Age group (years) } \\
\hline $60-69$ & 52 & $23.7(18.0-31.9)$ & 0.03 \\
\hline $70-79$ & 69 & $39.2(30.4-51.4)$ & \\
\hline 80 or over & 21 & $36.5(22.7-61.4)$ & \\
\hline All & 142 & $28.9(24.0-35.0)$ & \\
\hline \multicolumn{4}{|l|}{ Sex } \\
\hline Female & 79 & $24.0(18.9-30.8)$ & 0.02 \\
\hline Male & 63 & $37.7(28.3-51.1)$ & \\
\hline \multicolumn{4}{|l|}{ Color/Ethnicity } \\
\hline White & 101 & $31.0(25.0-39.0)$ & 0.88 \\
\hline Others & 36 & $29.8(20.6-44.3)$ & \\
\hline \multicolumn{4}{|l|}{ Marital status } \\
\hline Married & 87 & $33.1(26.3-42.2)$ & 0.06 \\
\hline Others & 55 & $23.0(17.0-31.7)$ & \\
\hline \multicolumn{4}{|l|}{ Family arrangement } \\
\hline Living alone & 15 & $17.9(9.9-35.5)$ & 0.11 \\
\hline Accompanied & 27 & $30.5(25.1-37.3)$ & \\
\hline \multicolumn{4}{|l|}{ Literacy } \\
\hline Literate & 105 & $27.9(22.5-34.8)$ & 0.43 \\
\hline Illiterate & 37 & $33.0(23.0-48.7)$ & \\
\hline \multicolumn{4}{|l|}{ Years of schooling } \\
\hline None & 29 & $27.8(18.5-43.2)$ & 0.89 \\
\hline 1 to 6 & 92 & $30.0(23.8-38.2)$ & \\
\hline 7 or more & 20 & $26.7(17.0-44.0)$ & \\
\hline \multicolumn{4}{|l|}{ Income (minimum wages) } \\
\hline Less than 1 & 50 & $29.9(21.7-42.2)$ & 0.41 \\
\hline 1 to 2.99 & 49 & $33.1(24.2-46.3)$ & \\
\hline 3 or more & 43 & $24.7(17.9-34.7)$ & \\
\hline \multicolumn{4}{|l|}{ Income perception } \\
\hline Sufficient & 45 & $27.0(19.5-38.1)$ & 0.56 \\
\hline Insufficient & 96 & $30.1(24.0-38.1)$ & \\
\hline \multicolumn{4}{|l|}{ Occupational group } \\
\hline Forces/Executive/Intellectual & 9 & $20.5(10.0-47.8)$ & 0.02 \\
\hline Administrative/Services/Higher secondary qualifications & 60 & $24.6(18.5-33.5)$ & \\
\hline Agriculture-livestock/Industrial/Maintenance & 65 & $40.5(31.0-53.7)$ & \\
\hline \multicolumn{4}{|l|}{ Position in occupation } \\
\hline Worker/Laborer/Rural & 88 & $30.3(24.0-38.9)$ & 0.99 \\
\hline Employer/Boss & 9 & $31.0(14.0-79.1)$ & \\
\hline Others & 40 & $29.6(21.1-42.7)$ & \\
\hline
\end{tabular}


Table 2

Self-reported hearing loss incidence (per 1,000 person-years) among elderly individuals according to factors related to self-perception of health, life style, self-reported morbidities and use of medications. The SABE study, São Paulo, Brazil, 2000 and 2006.

\begin{tabular}{|c|c|c|c|}
\hline Variable & n & Incidence $(95 \% \mathrm{Cl})$ & p-value \\
\hline \multicolumn{4}{|l|}{ Self-perception of health } \\
\hline Very good/Good & 60 & $23.2(17.6-31.2)$ & 0.02 \\
\hline Fair/Bad/Very bad & 80 & $35.5(27.7-46.0)$ & \\
\hline \multicolumn{4}{|l|}{ Self-reported visual deficiency } \\
\hline No & 15 & $23.7(13.5-45.0)$ & 0.42 \\
\hline Yes & 127 & $29.5(24.3-36.2)$ & \\
\hline \multicolumn{4}{|l|}{ Tobacco use } \\
\hline Never smoked & 70 & $23.2(17.9-30.4)$ & 0.01 \\
\hline Current smoker/Previous smoker & 72 & $36.7(28.3-48.4)$ & \\
\hline \multicolumn{4}{|l|}{ Diabetes } \\
\hline No & 120 & $28.7(23.4-35.6)$ & 0.76 \\
\hline Yes & 22 & $31.2(20.3-50.0)$ & \\
\hline \multicolumn{4}{|l|}{ Hypertension } \\
\hline No & 67 & $28.4(21.7-37.6)$ & 0.77 \\
\hline Yes & 75 & $29.9(23.2-39.1)$ & \\
\hline \multicolumn{4}{|l|}{ Osteoarticular diseases } \\
\hline No & 97 & $29.0(23.2-36.6)$ & 0.97 \\
\hline Yes & 44 & $29.2(21.0-41.6)$ & \\
\hline \multicolumn{4}{|l|}{ Neoplasia } \\
\hline No & 138 & $28.7(23.8-34.9)$ & 0.54 \\
\hline Yes & 4 & $39.0(13.2-154.4)$ & \\
\hline \multicolumn{4}{|l|}{ Cardiovascular diseases } \\
\hline No & 121 & $29.3(24.0-36.1)$ & 0.41 \\
\hline Yes & 19 & $23.8(14.2-42.4)$ & \\
\hline \multicolumn{4}{|l|}{ Osteoporosis } \\
\hline No & 113 & $27.0(21.8-33.6)$ & 0.08 \\
\hline Yes & 25 & $40.5(27.1-62.7)$ & \\
\hline \multicolumn{4}{|l|}{ COPD } \\
\hline No & 122 & $27.7(22.7-34.2)$ & 0.22 \\
\hline Yes & 20 & $38.6(23.7-66.5)$ & \\
\hline \multicolumn{4}{|l|}{ Dizziness } \\
\hline No & 109 & $27.7(22.5-34.5)$ & 0.39 \\
\hline Yes & 33 & $33.5(22.8-50.9)$ & \\
\hline \multicolumn{4}{|l|}{ Symptoms of depression } \\
\hline No & 111 & $27.8(22.5-34.6)$ & 0.46 \\
\hline Yes & 23 & $33.4(21.7-53.7)$ & \\
\hline \multicolumn{4}{|l|}{ Probable dementia } \\
\hline No & 138 & $26.9(8.5-117.4)$ & 0.84 \\
\hline Yes & 4 & $28.9(24.0-35.1)$ & \\
\hline \multicolumn{4}{|l|}{ Use of medications } \\
\hline No & 21 & $17.8(10.8-31.2)$ & 0.03 \\
\hline Yes & 121 & $32.0(26.3-39.4)$ & \\
\hline \multicolumn{4}{|l|}{ Hormonal reposition use } \\
\hline No & 68 & $25.1(19.1-33.6)$ & 0.77 \\
\hline Yes & 17 & $22.5(13.8-39.1)$ & \\
\hline \multicolumn{4}{|l|}{ Occupational morbidity } \\
\hline No & 105 & $30.6(24.7-38.4)$ & 0.90 \\
\hline Yes & 11 & $32.0(16.6-68.3)$ & \\
\hline
\end{tabular}

COPD: chronic obstructive pulmonary disease. 
Cox regression, incidence (per 1,000 person-years) and relative risk (RR) of self-reported hearing loss among elderly individuals according to sociodemographic variables and morbidity. The SABE study, São Paulo, Brazil, 2000 and 2006.

\begin{tabular}{|c|c|c|c|c|}
\hline Variable & n & Incidence & $\begin{array}{l}\text { Adjusted RR } \\
(95 \% \mathrm{Cl})\end{array}$ & p-value \\
\hline \multicolumn{5}{|l|}{ Age group (years) } \\
\hline $60-69$ & 52 & 23.7 & 1.0 & 0.02 \\
\hline $70-79$ & 69 & 39.2 & $1.5(0.9-2.5)$ & \\
\hline 80 and over & 21 & 36.5 & $1.7(1.1-2.8)$ & \\
\hline \multicolumn{5}{|l|}{ Sex } \\
\hline Female & 79 & 24.0 & 1.0 & $<0.01$ \\
\hline Male & 63 & 37.7 & $1.8(1.2-2.8)$ & \\
\hline \multicolumn{5}{|l|}{ Occupational group } \\
\hline Forces/Executive/Intellectual & 9 & 20.5 & 1.0 & 0.04 \\
\hline Administrative/Services/Higher secondary qualifications & 60 & 24.6 & $1.4(0.6-3.0)$ & \\
\hline Agriculture-livestock/Industrial/Maintenance & 65 & 40.5 & $1.7(1.0-4.8)$ & \\
\hline \multicolumn{5}{|l|}{ Osteoporosis } \\
\hline No & 113 & 27.5 & 1.0 & 0.02 \\
\hline Yes & 25 & 40.5 & $1.7(1.1-3.0)$ & \\
\hline
\end{tabular}

when compared to the 60 to 69 year age group. Cruickshanks et al. 20 analyzed hearing loss incidence in Australians aged 50 years and over using objective measuring techniques (tone threshold audiometry). According to the authors, an $81 \%$ increase in the number of cases of hearing loss occurred in each of the five-year age brackets in the ten years after the initial study. Mitchell et al. 9 also detected clinical proof of higher rates of hearing loss incidence, confirming. a three-fold increase in hearing loss incidence for each 10year age bracket over 60 years of age in the five years following the initial study.

The reasons for the association between hearing loss and advancing age have been widely addressed by the literature 8,20,21 and include the following: aging of the internal structures of the cochlea and the auditory nerve 21 leading to sensorineural hearing loss; and length of time of exposure to factors that are detrimental to hearing, such as the use of certain medications, noise and certain diseases 3 .

Although hearing loss incidence was shown to be high in both men and women, men are $80 \%$ more susceptible to developing hearing loss than women. Other studies confirm that in the over 60-year age group hearing loss incidence is higher among men than in women, particularly in the medium and high frequency ranges 22 . Cruickshanks et al. ${ }^{8}$ reported that men presented a three times greater risk of developing hearing loss than women, with $\mathrm{OR}=2.7$ (95\%CI:
2.0-3.5). The same authors stated that such differences cannot be attributed to age differences or occupation, because the data was controlled for age and sex, and almost all participants were retired individuals. Contrary to previous assertions, some studies report 20 that the effects of exposure to occupational noise may continue even after exposure to the detrimental effects on the hearing structures has ended. This is however a highly controversial debate in the audiological literature. In the authors' opinion, the lesions caused by occupational noise may be subclinical in younger individuals but when these individuals reach a certain age these lesions may accentuate the effects of ageing on the internal structures of the cochlea, thereby exacerbating presbyacusia.

The risk of developing hearing loss was $70 \%$ higher in workers still engaged in occupations or whose last occupations were related to agriculture and livestock, forestry, hunting and fishing, the production of industrial goods and services, repair and maintenance sectors than in members of the armed forces, police and firemen, high level civil service administrators, administrators of civil society organizations of relevant public interest and of companies, managers, and professionals in the areas of Science and Arts. Cruickshanks et al. 20 showed that workers in the production and operational areas of industries, services and agriculture were more susceptible to developing hearing loss than other professions 
(OR $=1.34 ;$ 95\%CI: 1.06-1.69), corroborating the findings of this study.

Numerous reports in the literature cite occupational noise as an important risk factor for hearing loss, especially in occupations where workers are exposed to noise levels above $85 \mathrm{~dB}$ NA 23 , as is the case with many industries and with agricultural machinery operators. Hearing Loss Induced by Industrial Noise (HLIIN) is a typical modern occupational disease and one of the most common causes of acquired hearing loss in adults 24 . Solecki 25 , in a study conducted in Poland showed that the noise present in agricultural activities is another important risk factor threatening hearing, concluding that hearing loss prevalence among rural workers increases with the length of time individuals spend in the activity, particularly when exposure to noise lasts for over 30 years.

Such data serves to confirm the difficulties faced by hearing conservation programs that, despite being widely publicized, are limited in preventing this kind of deficiency, due to the lack of implementation of treatment/prevention protocols, low adherence rates among workers in the use of Personal Protective Equipment, or poor isolation of sound sources, especially in small and medium-sized industries and/or companies 26 .

Regarding osteoporosis, elderly individuals with this morbidity in the base study were $70 \%$ more likely to develop hearing loss than those without the condition. Helzner et al. 27 reported that the loss of bone mass associated with osteoporosis could serve as a biomarker for presbyacusia. According to the authors, alterations in bone density parameters were associated with hearing loss in elderly men, but no such association was found among women. However, Clark et al. 28 reported that femoral bone loss in older women is associated with hearing loss in the 60 to 86-year age group (OR $=1.9$; 95\%CI: $1.3-2.5$ ). The probable explanation for this association is that the process of demineralization of the bone tissues typical of osteoporosis also affects the bone structures in the hearing system, including the cochlear capsule and the internal acoustic meatus 28 .

One of the methodological limitations of this study is the fact that estimates of hearing loss incidence are based on self-reported data and assumptions made regarding time of onset of the condition. It is possible that data concerning hearing loss incidence may be underestimated, since hearing loss may develop slowly and gradually in the beginning and elderly individuals may sometimes fail to self-report the condition even when it is present. On the other hand, incidence may have been overestimated due to a number of factors, including the decline in cognitive performance and deterioration in memory due to aging. However, considering the significant incidence of hearing loss and its negative effects, and given the dearth of information on this condition and associated risk factors among the elderly in Brazil, this study is a relevant contribution to widening the understanding of the auditory health of this age group and formulating future studies using objective methodologies.

It is also important to emphasize that this data provides important inputs to support and guide the formulation of public policies directed at this condition. Two of the factors associated with higher incidence - occupation and osteoporosis - should benefit from prevention measures. Thus, it is our recommendation that public health policies and actions in São Paulo designed to minimize the risks of this deficiency should firmly address these two factors as a way of minimizing hearing loss among the elderly. 


\section{Resumen}

El objetivo fue estimar la incidencia de pérdida de audición auto-reportada por ancianos en São Paulo, Brasil, y factores de riesgo asociados. Se realizó estudio longitudinal en 2006, con base en la población de 60 años o más entrevistada en el año 2000. La muestra se obtuvo por el método de muestreo por conglomerados en dos etapas, según el criterio de reparto proporcional a su tamaño, y la sustitución con una probabilidad proporcional a la población, para los sujetos de 75 años o más. El análisis estadístico se realizó mediante la prueba de razón de verosimilitud para la igualdad de las curvas de supervivencia y regresión de Cox. Se entrevistaron 765 ancianos, con una tasa de incidencia de pérdida de audición auto-reportada de 28,9/1.000 personas-año y una proporción de 17,4\%. Los factores de riesgo son la edad mayor o igual a 80 años, sexo masculino, ocupaciones en los sectores industrial, agrícola o de manutención, y la osteoporosis. Se deben desarrollar medidas de mitigación de riesgos para disminuir la incidencia de pérdida de audición entre los ancianos, especialmente las relacionadas con la prevención de ruido en el trabajo y de las enfermedades, especialmente, la osteoporosis.

Pérdida Auditiva; Salud del Anciano; Anciano

\section{Contributors}

M. S. Cruz contributed with the literature review, data analysis, writing and review of the article. M. C. P. Lima contributed with the study design, data analysis and interpretation, drafting and final approval of the article. J. L. F. Santos participated in the data analysis, statistical analysis and reviewed the article. M. L. Lebrão contributed with the study design and data analysis, and reviewed the article. Y. A. O. Duarte contributed with the study design, organization of the database, data analysis and interpretation, and critical review of the article. A. T. A. Ramos-Cerqueira contributed with the database design, data analysis, writing the results, and final approval of the article.

\section{Acknowledgments}

We are grateful to FAPESP (process 2005/54947-2) for their financial support.

\section{References}

1. Cruickshanks KJ, Wiley TJ, Tweed T, Klein BEK, Klein R, Mares-Perlman JA, et al. Prevalence of hearing loss in older adults in Beaver Dam, Wisconsin: the Epidemiology of Hearing Loss Study. Am J Epidemiol 1998; 148:879-86.

2. Gates GA, Couropmitree NN, Myers RH. Genetic associations in age-related hearing thresholds. Arch Otolaryngol Head Neck Surg 1999; 125:654-9.

3. Helzner EP, Cauley JA, Pratt SR, Wisniewski SR, Zmuda JM, Talbott EO, et al. Race and sex differences in age-related hearing loss: the health, aging and body composition study. J Am Geriatr Soc 2005; 53:2119-27.

4. Cacciatore F, Napoli C, Abete P, Marciano E, Triassi M, Rengo F. Quality of life determinants and hearing function in an elderly population: Osservatorio Geriatrico Campano Study Group. Gerontology 1999; 45:323-8

5. Desai M, Pratt L, Lentzner H, Robinson K. Trends in vision and hearing among older Americans. Aging Trends 2001; (2):1-8.
6. Agrawal Y, Platz EA, Niparko JK. Prevalence of hearing loss and differences by demographic characteristics among US adults. Arch Intern Med 2008; 168:1522-30.

7. Pleis JR, Coles R. Summary health statistics for U.S. adults: National Health Interview Survey, 1999. Vital Health Stat 10 2003; (212):1-137.

8. Cruickshanks KJ, Tweed TS, Wiley TL, Klein BEK, Klein R, Chappell R, et al. The 5-year incidence and progression of hearing loss: The Epidemiology of Hearing Loss Study. Arch Otolaryngol Head Neck Surg 2003; 129:1041-6.

9. Mitchell P, Gopinath B, Wang JJ, McMahon CM, Schneider J, Rochtchina E, et al. Five-year incidence and progression of hearing impairment in an older population. Ear Hear 2010; 32:1-7.

10. Cruz MS, Oliveira LR, Carandina L, Lima MCP, César CLG, Barros MBA, et al. Prevalência de deficiência auditiva referida e causas atribuídas: um estudo de base populacional. Cad Saúde Pública 2009; 25:1123-31. 
11. Coelho Filho JM, Ramos LR. Epidemiologia do en velhecimento no Nordeste do Brasil: resultados de inquérito domiciliar. Rev Saúde Pública 1999; 33:445-53.

12. Béria JU, Raymann BCW, Gigante LP, Figueiredo ACL, Jotz G, Roithman R, et al. Hearing impairment and socioeconomic factors: a population-based survey of an urban locality in southern Brazil. Rev Panam Salud Pública 2007; 21:381-7.

13. Mattos LC, Veras RC. A prevalência da perda auditiva em uma população de idosos da cidade do Rio de Janeiro: um estudo seccional. Rev Bras Otorrinolaringol 2007; 73:654-9.

14. Lebrão ML, Laurenti R. Saúde, bem-estar e envelhecimento: o estudo SABE no município de São Paulo. Rev Bras Epidemiol 2005; 8:127-41.

15. Sheikh JI, Yesavage JA. Geriatric Depression Scale (GDS): recent evidence and development of a short version. Clin Gerontol 1986; 5:165-73.

16. Icaza MC, Albala C. Minimental State Examination (MMSE) del estudio de dementia en Chile: análisis estadístico. Washington DC: Pan American Health Organization; 1999.

17. Folstein MF, Folstein SE, McHugh PR. A practical method for grading the cognitive state of patient for the clinician. J Psychiatr Res 1975; 12:189-98.

18. Pfeffer RI, Kurosaki TT, Harrah Jr. CH, Chance JM Filos S. Measurement of functional activities in older adults in the community. J Gerontol 1987 37:323-9.

19. Lee F-S, Matthews LJ, Dubno JR, Mills JH. Longitudinal study of pure-tone thresholds in older persons. Ear Hear 2005; 26:1-11.

20. Cruickshanks KJ, Nondahl DM, Tweed TS, Wiley TL, Klein BE, Klein R, et al. Education, occupation, noise exposure history and the 10-yr cumulative incidence of hearing impairment in older adults. Hear Res 2010; 264:3-9.
21. Gates GA, Mills JH. Presbycusis. Lancet 2005; 366:1111-20.

22. Kim S, Lim EJ, Kim HS, Park JH, Jarng SS, Lee SH. Sex differences in a cross sectional study of agerelated hearing loss in Korean. Clin Exp Otorhinolaryngol 2010; 3:27-31.

23. May JJ. Occupational hearing loss. Am J Ind Med 2000; 37:112-20.

24. Thorne PR, Ameratunga SN, Stewart J, Reid N, Williams W, Purdy SC, et al. Epidemiology of noise induced hearing loss in New Zealand. N Z Med J 2008; 121:33-44.

25. Solecki L. Comparative analysis of occupational hearing loss risk among private farmers with reference to decision-making criteria contained in the cabinet ordinances (current and previous). Med $\mathrm{Pr}$ 2005; 56:451-60.

26. Daniell WE, Swan SS, McDaniel MM, Camp JE, Cohen MA, Stebbins JG. Noise exposure and hearing loss prevention programmes after 20 years of regulations in the United States. Occup Environ Med 2006; 63:343-51.

27. Helzner EP, Cauley JA, Pratt SR, Wisniewski SR, Talbott EO, Zmuda JM, et al. Hearing sensitivity and bone mineral density in older adults: the Health, Aging and Body Composition Study. Osteoporos Int 2005; 16:1675-82.

28. Clark K, Sowers MR, Wallace RB, Jannausch ML Lemke J, Anderson CV. Age-related hearing loss and bone mass in a population of rural women aged 60 to 85 years. Ann Epidemiol 1995; 5:8-14.

Submitted on 13/Jul/2012

Final version resubmitted on $08 /$ Oct $/ 2012$

Approved on 17/Oct/2012 